\title{
Microstructure and Tribological Properties of Spheroidal Graphite Cast Irons with Nanoadditives
}

\author{
Julieta KALEICHEVA, Valentin MISHEV, Vlatko MARUŠIĆ
}

\begin{abstract}
In this paper metallographic, mechanical and tribological tests of spheroidal graphite cast iron with applied nanosized additives of titanium nitride + titanium carbonitride (TiN + TiCN), titanium nitride TiN and cubic boron nitride $\mathrm{CBN}$ are perfomed. With the aim to achieve upper bainite structure, samples of spheroidal graphite cast iron are put under austhempering at the following conditions: heating at $900^{\circ} \mathrm{C}, 1 \mathrm{~h}$ and isothermal retention at $380^{\circ} \mathrm{C}, 2 \mathrm{~h}$. In order to achieve the wear resistance, the resulting structure of the upper bainite has similar properties as martensitic structure, but with improved toughness. By X-ray analysis before and after the wear resistance test, the share of retained austenite was reduced in samples with applied nanosized additives compared to the samples of spheroidal graphite cast iron that were tested without the application of nanosized additives. Based on the analysis of the test results it was concluded that the samples with applied nanosized additives increased wear resistance compared to the samples that were tested without the application of nanosized additives.
\end{abstract}

Keywords: austempered ductile iron; hardness; microstructure; nanoadditives; upper bainite; wear resistance

\section{INTRODUCTION}

Small quantities of nanosized particles, added to the melt, exert influence on the characteristics of graphite phase in cast irons. The changes are observed in the graphite quantity and morphology. The nanoadditives influence the graphite phase, combined with the structure changes of the metal base, lead to the increase of cast irons wear resistance $[1 \div 5]$. The austempering is a type of heat treatment leading to the ductile cast iron metal base bainitic transformation. Austempered ductile irons (ADI) possess both high strength and durability with increased toughness and plasticity.

The austempering is applicable in the heat treatment practice of spheroidal graphite cast irons and structural steels and of some hypereutectoid and ledeburite steels $[6 \div 10]$. The receiving of new data on austenite-to-bainite transformation in iron-carbon alloys with nanosized particles expands the possibility of a wider use of austempering in the heat treatment of these alloys.

This paper presents the results of microstructure, hardness and tribological properties of spheroidal graphite cast irons with nanosized particles of (TiN+TiCN), TiN and $\mathrm{cBN}$ after casting and after austempering.

\section{METHODOLOGY OF INVESTIGATION}

Non-alloyed spheroidal graphite cast iron samples with the following composition: $\mathrm{Fe}-3,55 \mathrm{C}-2,67 \mathrm{Si}-$ $0,31 \mathrm{Mn}-0,009 \mathrm{~S}-0,027 \mathrm{P}-0,040 \mathrm{Cu}-0,025 \mathrm{Cr}-0,08 \mathrm{Ni}-$

$0,06 \mathrm{Mg} \mathrm{wt} \%$ are studied. On the nanoparticles used, an electroless nickel coating is applied before their introduction into the melt of the cast iron [11].

The additives plated with nickel are better homogenised during casting. The microstructure of the cast iron samples is observed by means of the OM and SEM analysis. For this purpose an optical metallographic microscope GX41 OLIMPUS and scanning electronic microscope EVO ${ }^{\circledR}$ MA10 "Carl Zeiss" are used. The cast irons are chemically treated in 2 vol. $\% \mathrm{HNO}_{3}-\mathrm{C}_{2} \mathrm{H}_{5} \mathrm{OH}$ their structure to be shown. The spheroidal graphite cast iron samples are undergoing austempering, including austenitizing at $900{ }^{\circ} \mathrm{C}, 1 \mathrm{~h}$, after that isothermal retention at $380{ }^{\circ} \mathrm{C}, 2 \mathrm{~h}$. The samples hardness is measured by Vickers method.

An abrasion test of austempered ductile iron samples is performed with and without nanoadditives. The experimental wear test is performed in a friction condition of a fixed abrasive by a cinematic scheme "pin - disc" according to the methodology described in the work [3].

The main experimental parameters are: nominal contact pressure, $P_{\mathrm{a}}=0.4 \times 10^{6} \mathrm{~Pa}$; average sliding speed, $V$ $=0.245 \mathrm{~m} / \mathrm{s}$; nominal contact surface, $A_{\mathrm{a}}=50.24 \mathrm{~mm}^{2}$; dencity, $\rho=7.80 \times 10^{3} \mathrm{~kg} / \mathrm{m}^{3}$. Impregnated material Corundum 220 is used as an abrasive in the experiment.

The amount of retained austenite in austempered ductile iron samples is determined before and after tribological examination by X-Ray diffraction analysis. A Philips PW 1050 diffractometer, equipped with a $\mathrm{Cu}$ - tube and scintillation detector is used. Quantitative analysis is performed by BRASS - Bremen Rietveld Analysis and Structure Suite [12].

\section{EXPERIMENTAL RESULTS}

The test piece made of cast iron consists of ferrite, pearlite and graphite structure after casting, Fig. 1. The nanosized additives change the quantity and size of the graphite phase, as the pearlite and ferrite quantity in the cast iron structure [3,5]. Nanosized additives in the spheroidal graphite cast iron do not change the graphite shape. They decrease the average diameter of the graphite sphere $D_{\text {mid }}$ from 11,00 to $10,34 \mu \mathrm{m}$. The increase of the quantity of the graphite phase with $35 \div 94 \%$ and the change of the pearlite and ferrite quantity in the cast iron structure are observed in the presence of the nanosized particles [5].

SEM analysis of the fracture of the impact destructed cast iron sample with ( $\mathrm{TiN}+\mathrm{TiCN})$ nanoparticles additives, Fig. 2, shows the nanoparticles presence in the graphite. Distribution of the graphite spheres in the cast iron structure at a relatively small magnification is shown in Fig. 2a. At higher magnifications, Fig. 2b and 2c, it is possible to observe nanoparticles within the graphite phase. Nanoparticles probably play the role of nanomodifiers. This explains the reduction of the diameter 
Dmid and increase of the amount of the graphite spheres [5] in the cast iron structure with nanoadditions compared to those without.

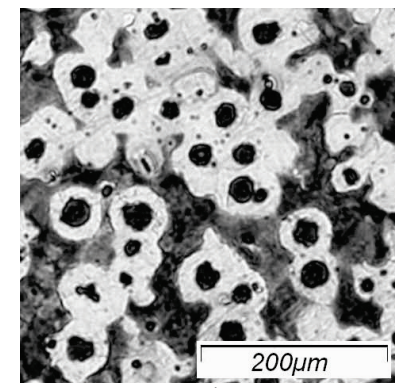

a)

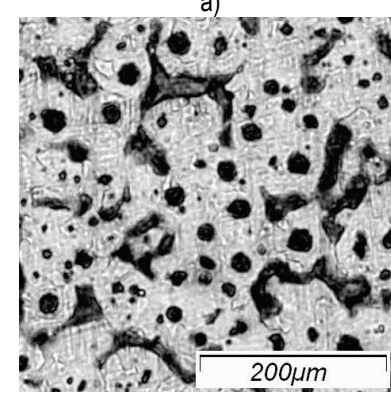

c)

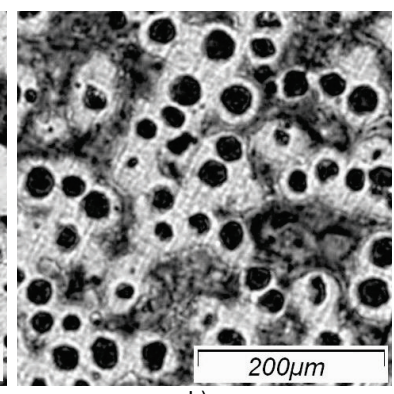

b)

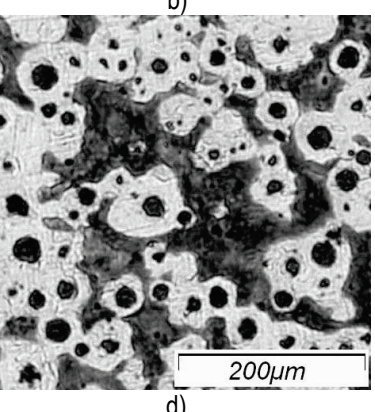

d)
Figure 1 Microstructure of spheroidal graphite cast irons:

a - without nanoadditives; $b$ - with TiN+TiCN; $c$ - with TiN; $d$-with cBN

The cast iron structure consists of upper bainite after austempering at $380{ }^{\circ} \mathrm{C}$ for 2 hours, Fig. 3. The bainite is an oriented needlelike grain structure of $\alpha$-phase (bainitic ferrite), carbides and untransformed austenite. The $\alpha$-phase is a carbon saturated $\alpha$-solid solution, forming by a martensitic mechanism in the low carbon austenite area. Upon cooling from the temperature of the isotherm to the ambient one, a part of the untransformed austenite undergoes martensitic transformation while the rest remains as a retained austenite in the structure $[6,7]$.

Nanosized additives change the bainitic ferrite morphology and the degree of the austenite transformation during austempering, Fig. 3. The austempered ductile iron samples hardness with upper bainite structure varies from 312 to 319 HV10, Fig. 4a, and the retained austenite quantity of the samples with nanoadditives is in the range of $27,1 \div 31,8 \%$, Tab. 1 .

Table 1 Nanosized additives, hardness and retained austenite

\begin{tabular}{|c|c|c|c|c|}
\hline \multirow{2}{*}{$\begin{array}{c}\text { No. of } \\
\text { sample }\end{array}$} & \multirow{2}{*}{$\begin{array}{c}\text { Nanosized } \\
\text { additives }\end{array}$} & \multirow{2}{*}{$\begin{array}{c}\text { Hardness } \\
\text { / HV10 }\end{array}$} & \multicolumn{2}{|c|}{$\begin{array}{c}\text { Retained austenite } \\
\text { A / \% }\end{array}$} \\
\cline { 4 - 5 } & & $\begin{array}{c}\text { Before } \\
\text { wear test }\end{array}$ & $\begin{array}{c}\text { After } \\
\text { wear test }\end{array}$ \\
\hline 1 & - & 314 & 40,4 & 31,3 \\
\hline 2 & TiN+TiCN & 319 & 27,1 & 11,6 \\
\hline 3 & TiN & 317 & 31,8 & 31,2 \\
\hline 4 & cBN & 312 & 30,2 & 25,3 \\
\hline
\end{tabular}

Nanosized additives in the austempered ductile irons change the bainitic transformation kinetics and accelerate the austenite transformation to bainite. The retained austenite quantity decreases from $40,4 \%$ for the samples without nanoadditives to $27,1 \div 31,8 \%$ for the samples with nanoadditives after 2 hours austempering at $380^{\circ} \mathrm{C}$, Tab.1.
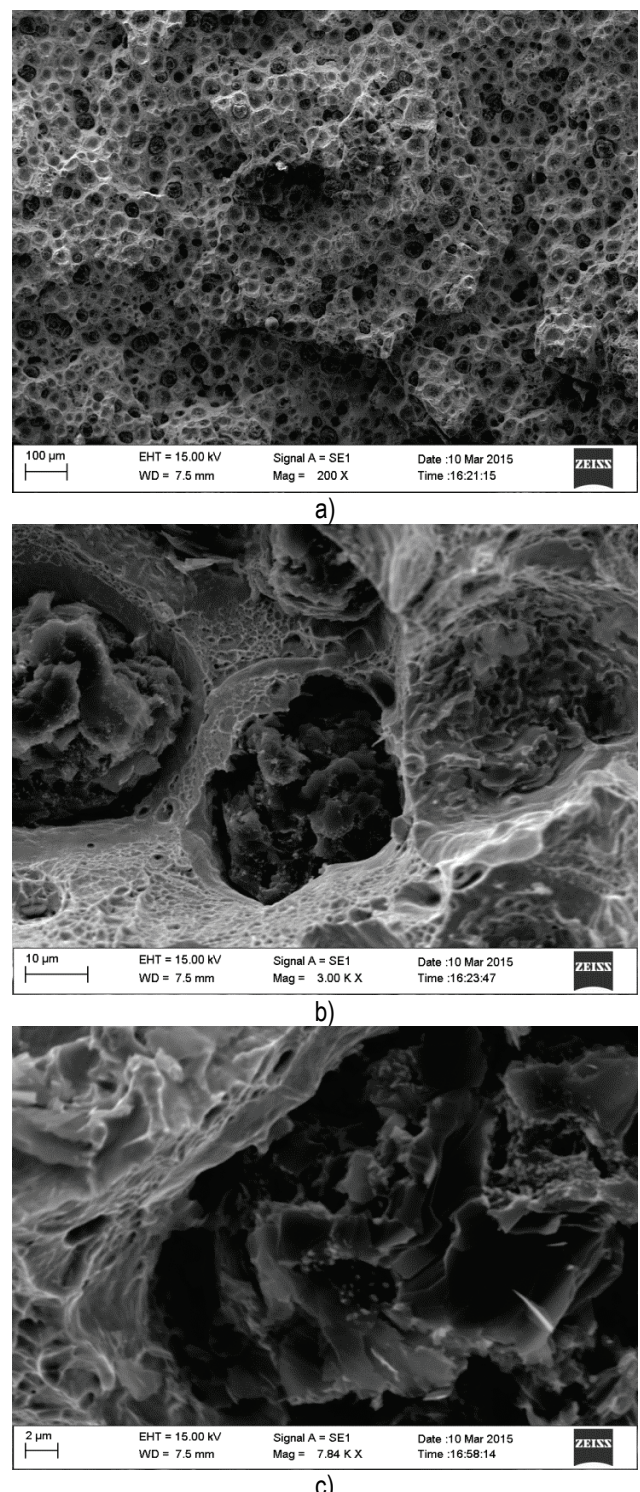

Figure 2 SEM analysis of the fracture of the impact destructed sample of spheroidal graphite cast irons with nanoadditives $(a, b, c)$
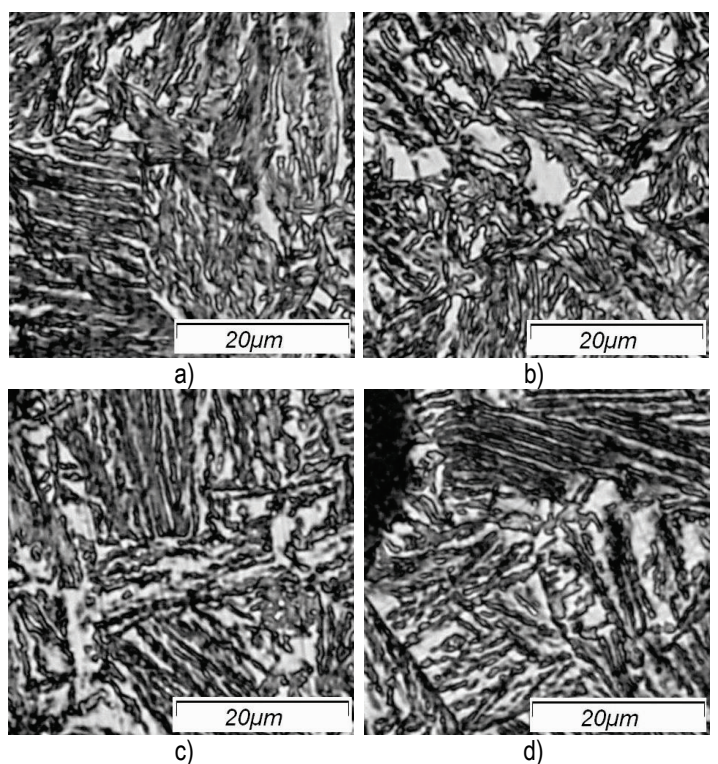

Figure 3 Upper bainitic microstructures

a - without nanoadditives; $b$ - with TiN+TiCN; $c$ - with TiN; $d$ - with cBN 


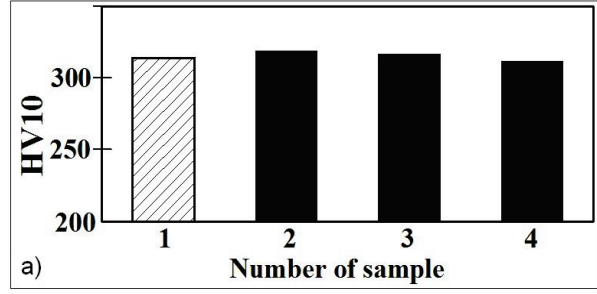$$
\text { a) }
$$

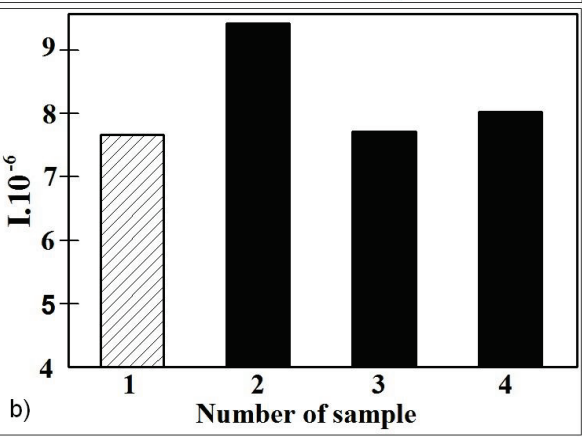

Figure 4 Hardness HV10 (a) and wear resistance $I(b)$ of samples from ADI: 1 -

without nanoadditives; 2 - with TiN + TiCN; 3 - with TiN ; 4 - with CBN

Tab. 2 presents the austempered ductile iron samples tribological tests. The following characteristics are defined: massive wear $m$, the speed of wear $\mathrm{d} m / \mathrm{d} t$, the absolute intensity wear $i$ and the absolute wear resistance $I$ and their alteration with the time of the contact interaction.

Fig. 5 shows the influence of the friction time $t$ on the wear rate $\mathrm{d} m / \mathrm{d} t$ and the cycles number $N$ (friction road) on the massive wear $m$.

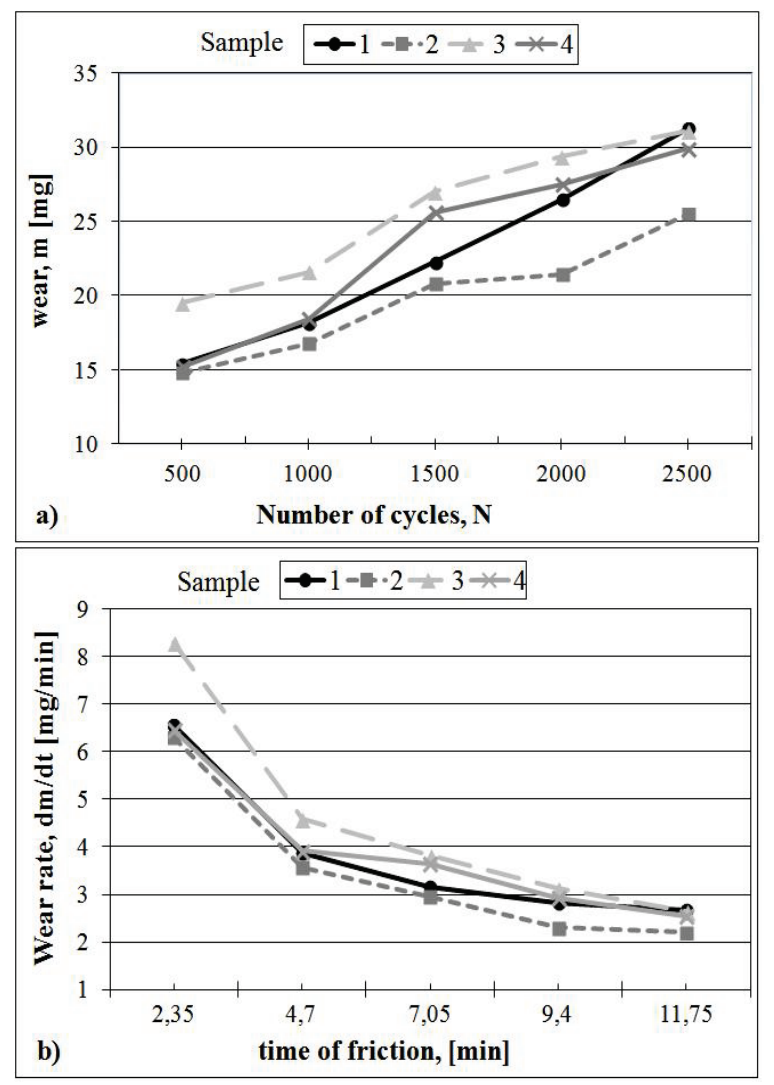

Figure 5 Influence of the cycles number $N$ on the massive wear $m(\mathrm{a})$ and the friction time $t$ on the wear rate $\mathrm{d} m / \mathrm{d} t$ (samples $1 \div 4$ )

Table 2 Massive wear $m$, wear rate $\mathrm{d} m / \mathrm{d} t$, intensity of wear $i$ and wear resistance $I$ of the samples 1-4

\begin{tabular}{|c|c|c|c|c|c|c|}
\hline \multicolumn{2}{|c|}{ Friction $\operatorname{road} L / \mathrm{m}$} & 122,5 & 245 & 367,5 & 490 & 612,5 \\
\hline \multicolumn{2}{|c|}{ Cycles number / N } & 500 & 1000 & 1500 & 2000 & 2500 \\
\hline \multicolumn{2}{|c|}{ Time $t / \min$} & 2,35 & 4,7 & 7,05 & 9,4 & 11,75 \\
\hline \multirow{4}{*}{ Massive wear $m / \mathrm{mg}$} & sample 1 & 15,4 & 18,2 & 22,3 & 26,5 & 31,3 \\
\hline & sample 2 & 14,8 & 16,8 & 20,8 & 21,4 & 25,5 \\
\hline & sample 3 & 19,5 & 21,6 & 27,0 & 29,4 & 31,1 \\
\hline & sample 4 & 15,2 & 18,4 & 25,6 & 27,5 & 29,9 \\
\hline \multirow{4}{*}{ Wear rate $\mathrm{d} m / \mathrm{d} t / \mathrm{mg} / \mathrm{min}$} & sample 1 & 6,55 & 3,87 & 3,16 & 2,82 & 2,66 \\
\hline & sample 2 & 6,30 & 3,57 & 2,95 & 2,30 & 2,20 \\
\hline & sample 3 & 8,30 & 4,60 & 3,83 & 3,13 & 2,65 \\
\hline & sample 4 & 6,47 & 3,91 & 3,63 & 2,92 & 2,54 \\
\hline \multirow{4}{*}{ Intensity of wear $i$} & sample 1 & $0,32 \times 10^{-6}$ & $0,19 \times 10^{-6}$ & $0,15 \times 10^{-6}$ & $0,14 \times 10^{-6}$ & $0,13 \times 10^{-6}$ \\
\hline & sample 2 & $0,30 \times 10^{-6}$ & $0,17 \times 10^{-6}$ & $0,14 \times 10^{-6}$ & $0,11 \times 10^{-6}$ & $0,10 \times 10^{-6}$ \\
\hline & sample 3 & $0,40 \times 10^{-6}$ & $0,22 \times 10^{-6}$ & $0,19 \times 10^{-6}$ & $0,15 \times 10^{-6}$ & $0,13 \times 10^{-6}$ \\
\hline & sample 4 & $0,32 \times 10^{-6}$ & $0,19 \times 10^{-6}$ & $0,18 \times 10^{-6}$ & $0,14 \times 10^{-6}$ & $0,12 \times 10^{-6}$ \\
\hline \multirow{4}{*}{ Wear resistance $I$} & sample 1 & $3,12 \times 10^{6}$ & $5,28 \times 10^{6}$ & $6,46 \times 10^{6}$ & $7,25 \times 10^{6}$ & $7,67 \times 10^{6}$ \\
\hline & sample 2 & $3,25 \times 10^{6}$ & $5,72 \times 10^{6}$ & $6,93 \times 10^{6}$ & $8,98 \times 10^{6}$ & $9,42 \times 10^{6}$ \\
\hline & sample 3 & $2,46 \times 10^{6}$ & $4,45 \times 10^{6}$ & $5,34 \times 10^{6}$ & $6,54 \times 10^{6}$ & $7,72 \times 10^{6}$ \\
\hline & sample 4 & $3,20 \times 10^{6}$ & $5,22 \times 10^{6}$ & $5,63 \times 10^{6}$ & $6,99 \times 10^{6}$ & $8,03 \times 10^{6}$ \\
\hline
\end{tabular}

The wear resistance $I$ of austempered ductile iron samples with upper bainite structure is measured for the same friction road $L=612,5 \mathrm{~m}$, Fig. $4 \mathrm{~b}$.

Metal material tribological properties significantly depend on the contact surface structure forming during the friction process. The metastable structures / retained austenite, martensite, bainite / structural transformations in the extensive plastic strain of the metal taking place in the friction contact area have a strong influence on the surface effective strength and on the materials tribological properties respectively. The dynamic strain aging refers to the initiated by the extensive plastic strain structural martensite transformation. The processes of the dynamic strain aging are characterized by formation of carbon atoms segregation on the friction arising dislocations. The strong fixing of impurities atoms to the dislocations causes the intensive strain strengthening of the high carbon martensite during the friction and its resistance increasing during different types of wear. The bainitic ferrite is a carbon saturated $\alpha$-solid solution, formed by a martensitic mechanism and the processes similar to those in $\alpha^{\mathrm{I}}-$ martensite occurs during friction.

The retained austenite is related to the metastable structures also, which undergoes strain $\gamma \rightarrow \alpha^{\mathrm{I}}$ martensitic transformation. The retained austenite converts partially into strain martensite during friction, containing the same carbon quantity as well as high carbon austenite and it is untempered martensite characterized by the high hardness and ability to intensive strengthening during wear. Figs. 6 and 7 present the results of the X-Ray analysis performed 
to determine the amount of the retained austenite in austempered ductile iron samples with $(\mathrm{TiN}+\mathrm{TiCN})$ and cBN nanoadditives before and after tribological testing. These results show that the retained austenite in the structure of these samples is converted partially into strain induced martensite during abrasive friction).
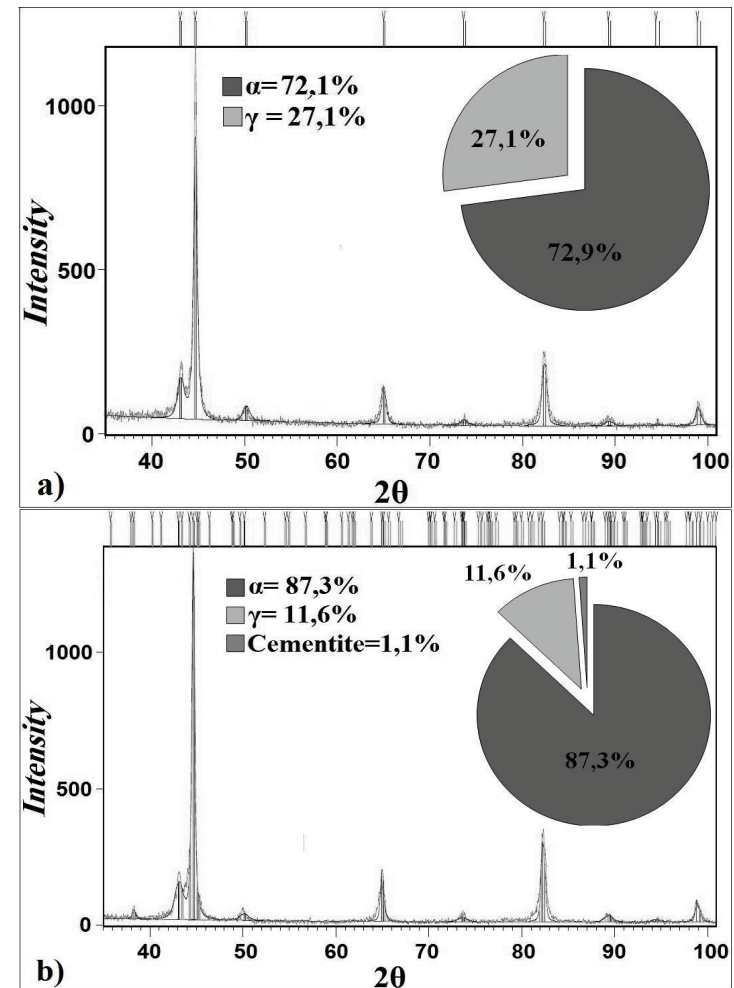

Figure 6 X-ray diffraction pattern of sample 2 from ADI with (TiN + TiCN) before (a) and after (b) tribological testing
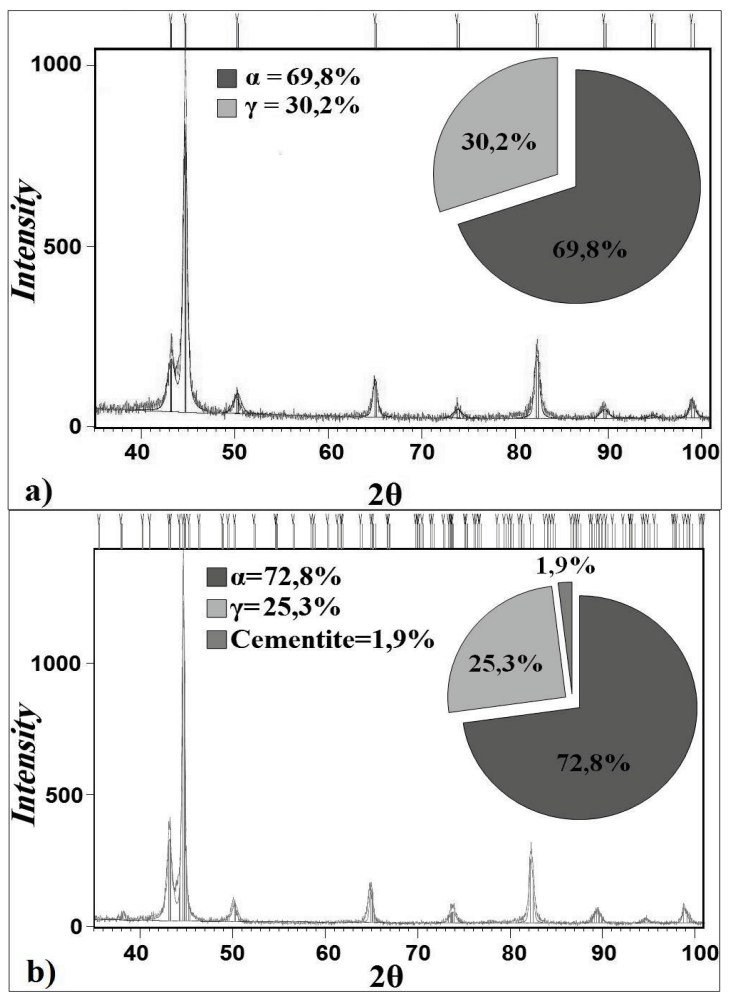

Figure $7 \mathrm{X}$-ray diffraction pattern of sample 4 from $\mathrm{ADI}$ with cBN before (a) and after (b) tribological testing

The wear resistance of these samples increases from 5 to $23 \%$ by comparison with the one of the cast iron without nanoadditives, Fig. 4b. The formation of the strain induced martensite from the metastable retained austenite in the friction contact area is probably one of reasons for the wear resistance increase of these cast irons.

\section{CONCLUSION}

The microstructure, tribological characteristics and hardness of austempered ductile irons, containing nanosized particles of $(\mathrm{TiN}+\mathrm{TiCN}), \mathrm{TiN}$ and $\mathrm{cBN}$ are investigated. The wear resistance of the upper bainitic cast irons with nanoparticles increases from 5 to $23 \%$ in comparison to the one of nanoparticles of free cast iron.

The observed effect of the nanoadditives on the graphite phase characteristics and on the extent of the transformation of the austenite to bainite explains higher abrasion wear resistance of the tested austempered ductile irons with nanoadditives compared to the same without nanoadditives. In austempered ductile irons, as a result of friction in the wear test, partial transformation occurs of the metastable retained austenite to strain induced martensite. This transformation influences increase of wear resistance of cast irons.

\section{REFERENCES}

[1] Wang, Y., Pan, Z., Wang, Z., Sun, X., \& Wang, L. (2011). Sliding wear behavior of $\mathrm{Cr}-\mathrm{Mo}-\mathrm{Cu}$ alloy cast irons with and without nanoadditives. Wear, 271, 2953-2962. https://doi.org/10.1016/j.wear.2011.06.015

[2] Kuzmanov, P., Dimitrova, R., Lazarova R., Cherepanov, A., \& Manolov, V. (2014). Investigation of the Structure and Mechanical Properties of Castings of Alloy AlSi7Mg, Cast Irons GG15 and GG25 and Steel GX120Mn12, Modified by Nanosized Powders. Journal of Nanoengineering and Nanosystems, 228(1), 11-18. https://doi.org/10.1177/1740349913510295

[3] Kaleicheva, J., Kandeva, M., Mishev, V., \& Karaguiozova, Z. (2013). Wear Behavior of Ductile Cast Irons with Nanoparticle Additives. J. Chem. Chem. Eng., 7(11), 10441049.

[4] Dimitrova, R., Kuzmanov, P., Lazarova, R., \& Manolov, V. (2013). Investigation of nanopowders application in metal casting. Advanced Materials Research, 629, 284-291. https://doi.org/10.4028/www.scientific.net/AMR.629.284

[5] Kaleicheva, J., Mishev, V., Lasarova, R., \& Karaguiozova, Z. (2015). Study of Spheroidal Graphite Cast Irons with Nanosized Additives. Nanoscience \& Nanotechnology Nanostructured Materials Application and Innovation Transfer, BAS, 15(1), 40-43.

[6] Bhadeshia, H. K. D. H. (2001). Bainite in Steels. $2^{\text {nd }}$ ed., Inst. of Materials, Cambridge, London, 2001.

[7] Dorasil, E. (1985). High-strenght Bainitic Nodular Cast Iron. Academia, Prague.

Haseeb, A. S. M. A., Islam, Md. A., \& Bepari, Md. M. A. (2000). Tribological behavior of quenched and tempered, and austempered ductile iron at the same hardness level. Wear, 244, 15-19.

https://doi.org/10.1016/S0043-1648(00)00404-X

Sahin, Y. \& Durak, O. (2007). Abrasive Wear behavior of Austempered Ductile Iron. Materials \& Design, 28 (6), 1844-1850. https://doi.org/10.1016/j.matdes.2006.04.015

[8] Caballero, F. G., Bhadeshia, H. K. D. H., Mawella, J. A., Jones, D. G., \& Brrown, P. (2002). Very strong low temperature bainite. Mater Sci Technol Lond., 18, 279-284. https://doi.org/10.1179/026708301225000725 
[9] Gavrilov, G. \& Nicolov, C. (1985). Electroless Nickel and Composite Coatings. Tehnika, Sofia.

[10] Birkenstock, J., Fischer, R. X., \& Messner, T. (2003). The Bremen Rietveld Analysis and Structure Suite (BRASS 2003). Ber. DMG, Beih. Z. Eur. J. Mineral., 15(1), 21.

\section{Contact information:}

Julieta KALEICHEVA, Full Prof., PhD

Technical University of Sofia,

Faculty of Industrial Technology,

$8 \mathrm{KI}$. Ohridski blvd., 1000 Sofia, Bulgaria

E-mail: jkaleich@tu-sofia.bg

Valentin MISHEV, Assist. Prof., PhD

Technical University of Sofia,

Faculty of Industrial Technology,

$8 \mathrm{Kl}$. Ohridski blvd., 1000 Sofia, Bulgaria

E-mail: v_mishev@tu-sofia.bg

Vlatko MARUŠIĆ, Prof. dr. Sc.

Mechanical Engineering Faculty in Slavonski Brod,

University of Josip Juraj Strossmayer in Osijek,

Trg Ivane Brlić-Mažuranić 2

35000 Slavonski Brod, Croatia

E-mail: vmarusic@sfsb.hr 